\title{
From Face-to-Face to Online UDeL Camps: Supporting Staff at Higher Education Institutions in Developing Universal Design for eLearning (UDeL)
}

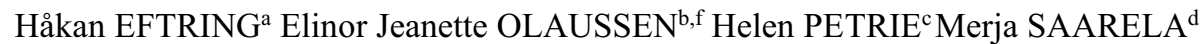 \\ Tarja LADONLAHTI ${ }^{\mathrm{e}}$ Anne Britt TORKILDSBY ${ }^{\mathrm{f}}$ \\ ${ }^{a}$ Certec, Department of Design Sciences, Lund University, Sweden \\ ${ }^{\mathrm{b}}$ Universell, Norway \\ ${ }^{\mathrm{c}}$ University of York, UK \\ ${ }^{\mathrm{d}}$ HÄME University of Applied Sciences, Finland \\ e University of Jyväskylä, Finland \\ ${ }^{\mathrm{f}}$ Norwegian Research Laboratory for Universal Design, Norwegian University of \\ Science and Technology, NTNU, Norway
}

\begin{abstract}
The TINEL Project is running a series of camps for staff at higher education institution to support them in developing inclusive eLearning. The first camp was conducted face-to-face, but the coronavirus pandemic meant that the second camp was conducted online. This created a case study in inclusive eLearning in itself and allowed us to experience and reflect on the challenges and opportunities of inclusive online teaching and learning. This paper presents the structure and content of the two camps, our reflections on moving from a face-to-face to an online situation and our elaboration how the UDL principles apply to eLearning to create Universal Design for eLearning (UDeL). We found that because we already had a syllabus for the camp prepared, transferring it to an online camp did not present a great number of challenges. Some aspects of the online situation were actually advantageous (e.g. presenting all materials digitally and making them fully accessible) while others were difficult to overcome (e.g. engaging all participants in online activities and discussions). We provide a set of recommendations of how to implement the three principles of UDL in eLearning situations.
\end{abstract}

Universal Design for eLearning (UDeL), Universal Design for Learning (UDL), Inclusive education, Equality, Higher Education Institutions, ERASMUS Plus

\section{Introduction}

Universal Design for Learning (UDL) aims to create quality learning experiences for all students regardless of their different skills and capabilities and their different backgrounds [1]. It is an extension of the concept of Universal Design (UD) proposed by Selwyn Goldsmith in the UK [2 - 4] and Ron Mace in the USA [5 - 7], that the design of products and environments should be "usable by all people, to the greatest extent possible, without the need for adaptation or specialized design" [5]. Goldsmith and Mace both came from architectural backgrounds and emphasized the design of the built environment, but the same principles can be applied to consumer products and now 
digital systems. Other researchers have referred to these ideas or very similar ideas as design for all [8], inclusive design [9], accessible design [10], universal usability [11]. See also [12] for a discussion of the terms.

UDL provides a framework for teachers, educational administrators and policy makers to improve and optimize teaching and learning for the broadest range of students. It is built on three main principles [13]:

- Provide multiple means of engagement (the "why" of learning)

- Provide multiple means of representation (the "what" of learning)

- Provide multiple means of action and expression (the "how" of learning)

These main principles are elaborated into a set of nine UDL Guidelines [14] which provide options and information on how to implement a more inclusive learning environment and support students and staff.

Increasingly higher education is moving to the use of digital technologies to create online and blended teaching and learning situations. Therefore, principles of UDL need to be elaborated to consider all aspects of the online or blended context of teaching and learning. The Web Content Accessibility Guidelines (WCAG), now in version 2.1 [15] (version 3.0 is currently in draft [16]), cover the accessibility of content on the Web for people with disabilities, but universal design of teaching and learning goes well beyond Web content and includes many more people than those with disabilities. It includes a wide range of learning and teaching situations such as online discussions and group work as well as access to and understanding of digital technologies. Thus, we propose the need for a Universal Design for eLearning or UDeL.

The TINEL Project [17], funded by the Erasmus+ Programme of the European Commission, aims to develop resources and practices to support UDeL in higher education institutions (HEIs). The focus is on the everyday use of UDeL in teaching and learning activities, and on questions about how to effectively implement UDeL. The TINEL Project includes a number of components. The first was to conduct an open call for best practices in UDeL, which took place in Spring 2019 [18] and highlighted four examples of best practice in a range of different contexts [19 - 22]. The second component is to run a series of four "camps" for staff from HEIs to develop their skills and share good practices in UDeL. The knowledge developed from both these components will be used to elaborate how the UDL principles apply to eLearning and build a training model for UDeL in HEIs. The training model will include a range of learning materials and a variety of different activities which can be undertaken to support staff and students in creating the most inclusive and engaging teaching and learning experiences in blended and online environments.

There are three incentives for developing a training model for UDeL. Firstly, as mentioned above, HEIs have been moving towards blended and online teaching and learning for some time. This move has been driven by two complementary changes in higher education. On the one hand, blended and online learning creates efficiency and flexibility for HEIs in times of increasing student numbers, an increasing diversity of students (including students with disabilities, international students and students from non-traditional backgrounds) and increasing staff costs. On the other hand, students are now very often "digital natives" who expect a digital world rather than a physical world. To keep them engaged, teaching needs to keep up with digital developments.

A second incentive is the Web Accessibility Directive of the European Union (EU) [23]. This was adopted in 2016 and set 23 September 2020 as the deadline by which all 
public sector websites in the EU must be accessible for people with disabilities. This includes websites for universities and has been interpreted to cover teaching materials and resources such as virtual learning environments (VLEs). Even the UK, although no longer an EU member state, has created a directive for HEIs, clearly stating that all digital resources should be accessible [24]. As mentioned, UDeL goes beyond consideration of the needs of people with disabilities, but this will be an important driver for HEIs to consider UDeL.

Finally, the coronavirus pandemic has forced HEIs across Europe and beyond to move their teaching, learning and assessment online at record speed, in order to be able to continue operating during the pandemic situation. What long-term effects this will have on the use of blended and online teaching and learning in HEIs is unclear. However, this situation also affected the TINEL Project and having run one camp as a three-day face-to-face event, we were forced to move our second camp to an online event. This allowed us and participants to learn more about UDeL, as we could "walk the talk" of creating an inclusive and engaging online teaching and learning event ourselves. The approach, format and activities developed for the second camp are therefore appropriate and relevant for the theme of UDeL, and even more transferable to participants' teaching practice.

This paper concentrates on the first and second TINEL Camps, how they were organized, how we adapted from a face-to-face to an online event, what we learned about UDeL from this process and suggestions to be considered when planning future events.

\section{The TINEL Camps and webinars}

The TINEL Project is planning four camps for HEI staff to introduce them to UDeL. The camps were originally planned to be three-day face-to-face events. Six to eight weeks after each camp there is a follow-up webinar to bring the participants back together again to reflect on what they learned at the camp and to discuss whether they have been able to progress with their case study (see below) since participating in the camp. Thus, the TINEL process was always conceptualized as a blended learning experience, with some face-to-face work and some online work. The first camp took place in Oslo in January 2020 and the second camp was held online in September 2020. Two further camps and accompanying webinars will be held during 2021.

One of the main principles for the camps was to base them around participants' own work, the challenges and issues they face in relation to making blended and online teaching and learning more inclusive and accessible. Thus, each participant brings a particular case study, that they are currently working on to the camp. They present the case study to all the participants and organizers for discussion and support, and hopefully during the course of the camp they make some progress with it. The case studies also expose all the camp participants to a range of different real-life issues in the area of UDeL.

The use of the case studies not only makes the content and learning in the camps more relevant to participants, it also makes it easier to apply what they have learned in the camp to their own work practices at their HEI. In addition, it should be interesting for participants to hear about others' case studies, helping them to learn from each other.

Another important principle of the camps is to try to create an open and welcoming atmosphere for the participants. This is to make people feel welcome and relaxed as well as open to sharing their real thoughts and concerns, without being afraid that their ideas 
are somehow "wrong" or not good enough. The TINEL project partners, who act as the camp organizers, try to initiate interesting topics for discussion rather than telling the participants "what the truth is". This should lead to more fruitful discussions about the concepts and the participants' case studies. In turn, this will lead to deeper learning about inclusive learning, UDL, and UDeL.

A final important principle of the camps is that they will create a peer support network for the participants to facilitate their future work with inclusive learning and UDeL. The UDeL Peer Support Network will consist of the TINEL project partners and interested participants from all the UDeL camps.

\subsection{UDeL learning materials}

UDeL learning materials for teaching and other staff at HEIs are being developed iteratively and tested throughout the four UDeL camps. Initial versions of the learning materials have been used in the first two camps and are being improved based on the feedback from the camp participants. The learning materials consist of UDeL Context Cards, videos, and articles.

The UDeL Context Cards is based on the Haptimap Context Cards [25, 26] and show a wide variety of situations for which a proactive teacher can be prepared. Each card shows a headline and an image on one side and a description of the situation on the other side. The UDeL Context Cards can be used as a tool for teachers to test a course in advance to see if they have thought of most situations that could occur in a course, especially in relation to student diversity and different learning situations and preferences.

The videos include ones with students talking about their experiences in different learning situations and ones with teachers talking about their experiences with different UDeL solutions focus on real world experiences staff can learn from.

A collection of articles about teachers' experiences of UDeL are used as the basis for discussions when training teaching and other staff in UDeL.

\subsection{UDeL Camp 1, Oslo, January 2020 (Physical camp)}

Teaching and other staff from the TINEL partner universities in Finland, Norway, Sweden and the UK were invited to the first UDeL camp, a three-day face-to-face event held in Oslo in January 2020. Nine people participated in the camp: six teaching staff one educational developer, one ICT advisor, and one MOOC project assistant.

Prior to the camp each participant submitted a digital presentation of themselves including their role, context, interest in inclusive eLearning, motivation to participate in the camp and example(s) of challenges they had experienced in relation to inclusive eLearning and UDeL. Following the UDeL philosophy, participants were invited to submit their presentation in whichever medium they preferred, so it might be a short video, a written text, or a slide pack. They were also asked to reflect on a possible case study from their work to concentrate on during and after the camp. In order to ensure a common understanding of the concepts of inclusive learning, UDL and UDeL, participants were sent a four-page written introduction to inclusive learning, UDL and UDeL and information about tools for inclusion as well as links to useful videos (all videos prepared by the TINEL team were captioned). 
Day 1 of Camp 1 comprised:

- Warm-up exercise to get to know each other.

- Presentations from the participants about themselves.

- Short introduction to the aims of the camp.

- Oral introduction to inclusive learning, UDL, and UDeL, to repeat and deepen the written introduction sent to participants prior to the camp.

- Group discussions about challenges each participant had experienced and their case study.

- An informal dinner to allow participants and organizers to get to know each other.

Day 2 comprised:

- Round table activities in small groups with discussions about:

- Learning materials: What kinds of resources and learning materials are needed in order to recruit colleagues and interest them in UDeL? This discussion started with the learning materials which participants received before the camp and on Day 1. Each participant also shared one success story related to UDeL practice - stories that had inspired them.

- Context cards: The UDeL Context Cards, including generating ideas for new cards based on participants' experiences.

- Technical tools: Experiences of technology and technical solutions used to support inclusive learning for a diversity of students.

- Sharing reflections from the round table discussions.

- Document accessibility: presentation, demonstration and hands-on exercises about how to use guidelines and tools to ensure document accessibility.

- A three-part presentation from a PhD student with a visual disability who also has a background in teaching. This included their experiences from a student perspective, from a teaching perspective and a more philosophical system view on disabilities and inclusion.

- Initial group discussion about the participants' case studies.

Day 3 comprised:

- Presentations and discussion of participants' case studies.

- Evaluation of the camp.

One week after the camp the participants were asked to complete a questionnaire about their experiences of the camp. It included questions about what they had learned and what is applicable in their own work; what they would pass on to colleagues about what they had learnt at the camp; comments about the different activities during the camp; what they felt was missing in the activities during the camp; and suggestions for future camps.

\subsection{Feedback from the UDeL Camp 1}

Five of the nine participants from Camp 1 completed the feedback questionnaire. Table 1 summarizes the comments they gave about the different camp activities. 
Table 1: Participants' comments for Camp 1.

\begin{tabular}{|l|l|}
\hline \multicolumn{1}{|c|}{ Content/activity } & \multicolumn{1}{c|}{ Comments } \\
\hline $\begin{array}{l}\text { Written introduction to } \\
\text { inclusive learning and } \\
\text { UDeL (before the camp) }\end{array}$ & $\begin{array}{l}\text { Well balanced both in content and volume. } \\
\text { Good. Clear. Brief. Just right. }\end{array}$ \\
\hline $\begin{array}{l}\text { Participants' video and/or } \\
\text { PowerPoint presentations } \\
\text { (to be posted online before } \\
\text { the camp) }\end{array}$ & $\begin{array}{l}\text { Several [presentations] were missing. Those there, were } \\
\text { interesting. }\end{array}$ \\
\hline $\begin{array}{l}\text { Introduction to inclusive } \\
\text { learning and UDeL (Day 1) }\end{array}$ & $\begin{array}{l}\text { Setting of atmosphere - camp leaders (+other participants) did } \\
\text { an excellent job of making me feel at home and at ease. }\end{array}$ \\
\hline $\begin{array}{l}\text { Group discussions about } \\
\text { participants' case studies }\end{array}$ & $\begin{array}{l}\text { We were a bit disorganized to begin with, thus did not get } \\
\text { enough time discussing. } \\
\text { Nice to have the opportunity to share similarities and } \\
\text { differences between the countries. }\end{array}$ \\
\hline $\begin{array}{l}\text { Round table activities } \\
\text { Great format for fairly quick results. } \\
\text { This was good, but a bit rushed. } \\
\text { [See also section 2.6] }\end{array}$ \\
\hline $\begin{array}{l}\text { Session about accessible } \\
\text { documents }\end{array}$ & Very usable in my work! \\
\hline $\begin{array}{l}\text { Experiences from the PhD } \\
\text { student with a visual } \\
\text { disability }\end{array}$ & $\begin{array}{l}\text { This was well worth the whole meeting. } \\
\text { Inspiring person and case - hope to see more examples and } \\
\text { presentations like this. } \\
\text { from colleagues }\end{array}$ \\
\hline $\begin{array}{l}\text { The idea is good, but we were all not prepared enough to } \\
\text { provide a well thought through 10-minute presentation. } \\
\text { Good structure, well prepared participants even though time } \\
\text { was limited, excellent leadership [from the organizers] with } \\
\text { feedback and timekeeping! }\end{array}$ \\
\hline
\end{tabular}

Their experiences were in general very positive, noting that the camp was a very well-organized event. They also emphasized the good structure of the camp and, as an important part of this kind of event, successful setting of tone and good atmosphere. According to their feedback, the camp was beneficial. They had learned a lot including new ideas (pedagogic examples), new skills (making accessible documents), new concepts or new framing (UDeL) and they were happy about their new contacts (e.g. to ask for help). Some of the participants emphasized the discussions with fellow participants and the materials provided and presentations.

To improve the camp, participants suggested it would be better to spread the camp over more days, allowing more time for discussions about issues raised, reflection and 
preparations of their final presentations. One suggestion was to have a presentation from a previous participant. Another participant would have appreciated more hands-on work regarding how to make documents and videos, accessible. A third participant would have liked to have some more participants at the camp.

\subsection{UDeL Camp 2, September 2020 (Online)}

Due to the coronavirus pandemic, Camp 2 was held completely online in September 2020. As with Camp 1, teaching and administrative staff from the TINEL partner universities in Finland, Norway, Sweden and the UK were invited. Ten people participated in Camp 2: five teaching staff, one educational developer, one librarian, two ICT specialists working as staff educators, and one MOOC project assistant.

This section will explain how the online camp was developed in reaction to the feedback from the first camp and the new situation, and then the schedule will be presented.

To adapt from a face-to-face camp to an online one, we made the following preparations and changes. The Zoom online communication system was used with the possibility of dividing the participants into separate breakout rooms for more active discussions in smaller groups. The camp was extended from three full days to five half days with several short breaks, as it would be too tiring for people to participate in an online meeting for up to eight hours a day and to leave time each day for participants' busy schedules at their home universities. However, it was approximately the same number of hours as the previous camp.

We pre-recorded the introduction lecture about inclusive learning and UDeL for Day 1 as three short videos (each 6 to 13 minutes long). This "flipped classroom" $[27,28]$ activity increased the flexibility for participants to study the video before the camp and to prepare questions for the discussion. We also added some free time to study these videos just before the discussion, to allow time to refresh one's memory for the content or to view the videos for those who had not had time to view them in advance. In addition, we pre-recorded a 16-minute video with experiences from a student with dyslexia, as an addition to the recording of the PhD student with a visual disability from Camp 1. Prerecording the videos, meant their technical quality was ensured and they could be accurately captioned, as they will be part of the learning materials provided for future use by the TINEL Project. We added some free time to study the last video just before a live discussion with the student. The reason for a live discussion was to increase the sense of presence at the camp and allow questions.

We added a discussion about pedagogical tools in the session about technical tools (one of the round table exercises), to explain what we meant by this term, and to encourage sharing a broader set of experiences and stories about all kinds of tools, including pedagogic tools such as Menti [29, 30] and Padlet [31,32]. In addition, we included more examples of UDeL Context Cards based on the experiences of Camp 1, to trigger a broader set of examples from participants. Finally, we removed the plenary discussion session after the round table exercises, to give time for more active group discussions about specific topics, which the participants were asked to suggest.

To support creation of the UDeL Peer Support Network we kept the social event and made it an online event at the end of the first day, to also create a welcoming and informal atmosphere to the online camp, which would facilitate constructive discussions during the rest of the camp. A lightheaded quiz was added at the end of Day 4, to create an 
opportunity for informal discussions and increase the possibilities for continued contact in the future.

The participants made the same preparations for Camp 2 as for Camp 1, that is a digital presentation of themselves in their preferred format and preparation of a possible case study from their work to concentrate on during and after the camp. They were also sent the introductory materials about inclusive learning, UDL, and UDeL, as well as links to videos for further learning.

Day 1 of the Camp 2 comprised:

- Warm-up exercise to get to know each other.

- Digital presentations from the participants about themselves.

- Short introduction to the aims of the camp.

- Free time to study the pre-recorded videos introducing inclusive learning, UDL, and UDeL.

- Discussions about inclusive learning, UDL, and UDeL based on the introductory videos.

- Social dinner event. It was suggested that participants make something to eat, perhaps something typical of their country or region, which they could then show to the group and eat together. This allowed us to discuss food from different countries and individual food preferences.

Day 2 comprised:

- Group discussions about challenges each participant had experienced and their case study.

- Round table activities in Zoom breakout rooms with discussions about:

- Learning materials: as in Camp 1.

- Context cards: as in Camp 1, with additional examples generated in Camp 1.

- Technical and pedagogical tools: expanded from Camp 1, as described above.

- Document and video accessibility: as in Camp 1, with an additional presentation of automatic captioning and a website with "just in time" information about accessibility for different formats developed at University of York.

Day 3 comprised:

- Free time to study the video by a student with dyslexia and to prepare questions for the discussion with the student.

- Live online discussions with the student with dyslexia.

- Small group discussions in Zoom breakout rooms about specific topics suggested by both the organizers and the participants (e.g. how to motivate teachers for inclusive learning, accessible documents and videos).

- Small group discussions in Zoom breakout rooms on the participants' case studies.

Day 4 comprised:

- Individual or joint preparation for the final presentations of the participants' case studies. 
- Presentations and discussion of participants' case studies and plans for how they would continue working on them after the camp.

- Social event: a lightheaded quiz to allow participants and organizers to interact in an informal way.

Day 5 comprised:

- Discussions of participants' case studies (continued from Day 4).

- Evaluation of the camp.

As for Camp 1, one week after the camp participants were asked to complete the feedback questionnaire. Updates from the questionnaire for Camp 1 included adjusting questions to the online camp format and adding two overall questions about experience and rating of the camp content.

\subsection{Feedback from the UDeL Camp 2 (online)}

Five of the ten participants from Camp 2 completed the feedback questionnaire. Table 2 summarizes their ratings for the overall experience and contents as well as their comments for the different activities of the camp.

\section{Table 2: Participants' overall ratings and comments for Camp 2 Ratings were on a scale of $1=$ poor to $5=$ excellent}

\begin{tabular}{|c|c|}
\hline Content/activity & Overall ratings and comments \\
\hline $\begin{array}{l}\text { How would you rate your } \\
\text { overall experience? }\end{array}$ & $\begin{array}{l}\text { Ratings from five of the ten participants: } \\
5,4,5,4,5 \text { (Median: } 5 \text { ) }\end{array}$ \\
\hline $\begin{array}{l}\text { How would you rate the } \\
\text { contents of the camp? }\end{array}$ & $\begin{array}{l}\text { Ratings from five of the ten participants: } \\
5,3,5,4,4 \text { (Median: } 4 \text { ) }\end{array}$ \\
\hline $\begin{array}{l}\text { Written introduction to } \\
\text { inclusive learning, UDL, } \\
\text { and UDeL (before the } \\
\text { camp) }\end{array}$ & $\begin{array}{l}\text { It's a good idea to have this flipped learning idea with pre-tasks. } \\
\text { The introductory materials were excellent. }\end{array}$ \\
\hline $\begin{array}{l}\text { Participants' video and/or } \\
\text { PowerPoint presentations } \\
\text { (before the camp) }\end{array}$ & $\begin{array}{l}\text { I participated poorly in getting to know the other participants } \\
\text { before camp. }\end{array}$ \\
\hline $\begin{array}{l}\text { Pre-recorded video } \\
\text { introduction to inclusive } \\
\text { learning, UDL, and UDeL } \\
\text { (day 1) }\end{array}$ & Excellent video materials. \\
\hline Online social dinner event & $\begin{array}{l}\text { The dinner event worked well - a great idea. } \\
\text { The first day was a bit too long. Perhaps the social event could } \\
\text { have been at a later point during the week? Or an added social } \\
\text { lunch? }\end{array}$ \\
\hline $\begin{array}{l}\text { Group discussions about } \\
\text { participants' case studies }\end{array}$ & $\begin{array}{l}\text { The participant cases and discussions were really interesting } \\
\text { because of differences between them. }\end{array}$ \\
\hline Round table activities & $\begin{array}{l}\text { Good discussions in the round table. } \\
\text { [See also section 2.6] }\end{array}$ \\
\hline
\end{tabular}




\begin{tabular}{|l|l|}
\hline $\begin{array}{l}\text { Session about accessible } \\
\text { documents and videos }\end{array}$ & $\begin{array}{l}\text { Very good session on accessible documents - this was at just } \\
\text { the right level. } \\
\text { The hands-on exercises could have been even more hands on. } \\
\text { The accessible documents part was very good but the bit about } \\
\text { videos and captioning went by so quickly I wasn't really able to } \\
\text { follow. I would have liked more time dedicated to the topic. }\end{array}$ \\
\hline $\begin{array}{l}\text { Discussions with the } \\
\text { student with dyslexia }\end{array}$ & $\begin{array}{l}\text { Real life examples by real people are always the best. } \\
\text { Excellent session about dyslexia. }\end{array}$ \\
\hline $\begin{array}{l}\text { Participants pitching their } \\
\text { case studies with feedback } \\
\text { from colleagues }\end{array}$ & $\begin{array}{l}\text { The presentations and discussion of the participants' case studies } \\
\text { were very constructive and useful for all participants - some } \\
\text { very targeted advice and ideas here. }\end{array}$ \\
\hline Social quiz & Social quiz was great! \\
\hline
\end{tabular}

Overall comments included positive comments about the way the camp was organized. "Cognitive load did not get too high as we had breaks" and the content was "a good blend of theoretical issues and specific targeted help/techniques/technologies."

As with Camp 1, participants mentioned that the material on how to make accessible documents was very beneficial, including how to check the accessibility of one's own documents. For one person, the most applicable "take away" for their own work was to realize in "how many ways you can approach the idea of accessibility in education". Some of the participants learned most from the discussions with fellow participants and organizers about their own case studies. The session with the student with dyslexia was also mentioned as very useful. Examples of what participants learned, and what was most applicable in their own work included new tips, ideas (e.g. other participants' case studies), specific methods and techniques (e.g. flipped learning) and new educational concepts applicable to inclusive teaching and learning (e.g. nano-learning [33]). During the camp one participant picked up ideas about how to run a successful collaborative workshop online, while another found it very useful to have wider scope for more theoretical/philosophical discussions. One participant made the following reflection: "It's not just about making learning and materials accessible and inclusive - it's about changing our mindsets".

Suggestions for the further development of the camps were also elicited. One of the participants said they did not have one: "I thought it was excellent and at just the right level. Thank you." There was also some of critical feedback, some related to timetable (the first two days felt a bit too long) and some to the discussion groups. One participant felt that there should be "Discussion groups without partners [organizers]. Partners tend to get an expert role and become too dominant in discussions." Some time for informal chats over coffee was suggested as a good opportunity to clarify topics.

\subsection{Feedback on the round table discussions at both camps}

We were particularly interested in how successful the round table discussions were, at both the face-to-face and online camps. This was a participation format which participants might have found challenging, particularly in the online format. This section presents the results from the three round table discussions at the camps: learning materials and sharing of success stories; UDeL Context Cards; and technical and 
pedagogical tools. No particular differences between the two camps were found, in spite of the different formats.

Learning materials. All participants found the learning materials useful. They appreciated the amount and breadth of content and the fact that there were multiple sources of information. Their suggestions for improvements included more extensive use of short videos and more examples on what works from both the student and teacher perspective.

Sharing of success stories. The participants related different kinds of experiences in this exercise. Their experiences can be divided in two categories: "sharing is caring" and "disclosure and alternative solutions".

"Sharing is caring" experiences related to feedback participants received from their colleagues and target groups when they shared recommendations and guidance on how to be more inclusive in their teaching. One example was a video with step-by-step guidance on how to create captions for a video.

"Disclosure and alternative solutions" experiences related to situations in which participants worked with students. Participants shared experiences about what worked well when students expressed difficulties and worked together with their teachers to find good alternatives that helped students succeed and overcome their challenges in the learning process. One example was a student who delivered a 3-minute video instead of a written report without asking for permission to do so. This made the teacher think and do things differently afterwards.

UDeL Context Cards. The discussions at the Context Card round tables resulted in 40 suggestions for new cards at Camp 1 and 24 further card suggestions at Camp 2. Intentionally, these were not situations directly related to students with disabilities, but to other situations, for example students' family or work situations, financial situations, language skills, or prior work experience. These suggestions also triggered discussions among the participants of their personal experiences of the variety of situations teachers often face and how they can be solved.

Technical and pedagogical tools. The general finding from the round table discussions about technical and pedagogical tools was that every university and every teacher has their own preferences and tools to design, implement and assess teaching and learning activities. There is a clear need for discussions about new tools, as teachers have limited time to find them, to understand how the tools can be used, what kind of pedagogical approaches can be implemented and what kind of disability-related issues can be addressed with the aid of these tools.

\subsection{Follow-up webinars}

International and national webinars follow each of the four UDeL camps in the TINEL Project. The international webinars after Camp 1 and 2 were held eight and six weeks after each camp using the Zoom communication system. In these webinars, participants briefly presented the current state of their case studies and received feedback and support from camp organizers and participants. 8 of the 9 participants from Camp 1 participated in the first follow-up webinar and 5 of the 10 participants from Camp 2 (and 1 participant from Camp 1) participated in the second follow-up webinar. The reasons for not participating were lecturing at the time of the webinar and one participant having left the university. For the remaining two follow-up webinars all previous camp participants will also be invited, to build towards the UDeL Peer Support Network. 
Each follow-up webinar is recorded, and participants' slide presentations are saved and shared among the participants and project partners. The webinar ends with a one minute "check-out" from each participant in which they share their learning during the whole process of participating in the TINEL Project.

A national webinar was held in Finland some weeks after the first international follow-up webinar, to share the results from Camp 1. Further national webinars will be held after each subsequent camp, targeting partner universities in Sweden, UK, and Norway.

\subsection{Feedback at the $2^{\text {nd }}$ International Follow-up webinar}

Table 3 presents the comments from the "check-out" by the five participants at the $2^{\text {nd }}$ international follow-up webinar.

Table 3: Participants' comments at the $2^{\text {nd }}$ International Follow-up webinar

\begin{tabular}{|l|l|}
\hline \multicolumn{1}{|c|}{ Participant } & \multicolumn{1}{c|}{ Comments } \\
\hline Participant 1 & $\begin{array}{l}\text { I have found it very very useful during the camp, and also this } \\
\text { webinar, to listen to my colleagues and to be able to reflect and } \\
\text { compare my own situation with yours and get many advices. } \\
\text { And especially, I think it is most useful to be able to take the } \\
\text { time to focus on the UDL questions. }\end{array}$ \\
\hline Participant 2 & $\begin{array}{l}\text { It has been a great pleasure to discuss with you, because we } \\
\text { share the same challenges, and we may learn from each other's } \\
\text { solutions. }\end{array}$ \\
\hline Participant 3 & $\begin{array}{l}\text { The camp had a very good structure for an online camp. I will } \\
\text { use the same structure when I will organize an online camp. } \\
\text { There were enough breaks, and it was activating and these kinds } \\
\text { of lectures we watched beforehand as video recordings. }\end{array}$ \\
\hline Participant 4 & $\begin{array}{l}\text { Nice to talk to people and hear your stories and cases and there } \\
\text { is so much peer support. Also, today, I have written some things } \\
\text { on my paper, tools I have to try out. }\end{array}$ \\
\hline Participant 5 & $\begin{array}{l}\text { The main thing I take away from the camp is the accessible } \\
\text { document session, which was really brilliant and really timely. }\end{array}$ \\
\hline
\end{tabular}

Three of the five participants focused on peer learning and said they learned a lot from other participants by listening to their case studies, discussing them, and comparing their challenges and solutions with their own situations. Additionally, they got advice and peer support from others on their own case studies. One of these participants also learned about tools to try out, and another one appreciated taking the time to focus on UDL.

One participant focused on the structure of the camp and its content. The structure and enough breaks fitted an online camp well. The camp was activating by using a flipped classroom structure with pre-recorded videos. Finally, one participant focused on the hands-on exercise about how to make accessible documents and videos, and thought it was brilliant. 
These comments from the follow-up webinar show that peer learning, using participants' real case studies at the camp, as well as the online camp structure and content were useful in applying UDeL into concrete practices.

\section{Discussion}

Comparing Camps 1 and 2 is more than a comparison on a face-to-face and an online camp. It is our goal to elaborate how the UDL principles apply to eLearning and develop a training model for UDeL for use beyond the lifetime of the TINEL Project, and the comparison of the two camps provides material for this elaboration. Table 4 summarizes how we applied the three main principles of UDL (multiple means of engagement, representation, action and expression) to the UDeL situation we encountered somewhat unexpectedly in the project and what we learned in relation to each. The table is divided into sections for planning and preparations for the camps and actual implementation of the camps.

Table 4: Reflections on Camp 1 and 2 in relation to the UDL principles

\begin{tabular}{|c|c|c|}
\hline Principle & Planning \& preparation & Implementation of the camp \\
\hline $\begin{array}{r}\text { How the } \\
\text { engagement of } \\
\text { the } \\
\text { participants } \\
\text { was } \\
\text { considered }\end{array}$ & $\begin{array}{l}\text { Common for Camp } 1 \text { \& } \mathbf{2} \\
\text { Participants sign up for } \\
\text { participation and are self- } \\
\text { motivated to participate. } \\
\text { It was mentioned what } \\
\text { activities were mandatory } \\
\text { vs. voluntary. } \\
\text { Participants were provided } \\
\text { with the full programme in } \\
\text { advance and what would } \\
\text { be expected from them. }\end{array}$ & $\begin{array}{l}\text { Common for Camp } 1 \text { \& } \mathbf{2} \\
\text { Participants choose their own case studies } \\
\text { to work with during and after the camp. } \\
\text { Participants are involved in developing } \\
\text { project outcomes (learning materials and } \\
\text { training model) through round table } \\
\text { exercise and evaluation of the camp. } \\
\text { We fostered collaboration and community } \\
\text { through interacting group work and social } \\
\text { dinner. } \\
\text { Participants received mastery-oriented } \\
\text { feedback from peers and organizers on their } \\
\text { presentations of case studies throughout the } \\
\text { camp and webinar. } \\
\text { Specific for Camp } 2 \\
\text { We fostered a community through social } \\
\text { activities like the quiz and digital dinner } \\
\text { where participants made a dish in their } \\
\text { preferred way. } \\
\text { Participants received more feedback from } \\
\text { each other and from organizers on } \\
\text { difficulties and their presentations of case } \\
\text { studies throughout the camp and webinar } \\
\text { compared to Campl. Discussions were } \\
\text { facilitated by project members. }\end{array}$ \\
\hline
\end{tabular}




\begin{tabular}{|c|c|c|}
\hline $\begin{array}{r}\text { How multiple } \\
\text { means of } \\
\text { representation } \\
\text { are used and } \\
\text { taught }\end{array}$ & $\begin{array}{l}\text { Common for Camp } 1 \& \mathbf{2} \\
\text { Information about the } \\
\text { camp, agenda and } \\
\text { preparatory tasks, where } \\
\text { only presented as written } \\
\text { text, but shared digital and } \\
\text { made universally designed. } \\
\text { Preparatory material } \\
\text { consisted of written } \\
\text { documents as a mandatory } \\
\text { activity and two videos as } \\
\text { voluntary. }\end{array}$ & $\begin{array}{l}\text { Common for Camp } \mathbf{1} \boldsymbol{\&} \mathbf{2} \\
\text { Mix of presentations in plenary, group } \\
\text { work, interactive activities. } \\
\text { Most activities were oral. } \\
\text { Provided physical resources and shared } \\
\text { recommended digital resources (articles, } \\
\text { videos, websites etc.). } \\
\text { Presentation from student perspective was } \\
\text { recorded and captioned and can be watched } \\
\text { countless of times. }\end{array}$ \\
\hline & $\begin{array}{l}\text { Specific for Camp } 2 \\
\text { The oral introduction to } \\
\text { UDeL from Camp } 1 \text { was } \\
\text { turned into three captioned } \\
\text { videos participants had } \\
\text { possibility to watch } \\
\text { before/during/after the } \\
\text { camp. }\end{array}$ & $\begin{array}{l}\text { Specific for Camp } 2 \\
\text { Participants learn more experiences from } \\
\text { students with disabilities because they have } \\
\text { access to digital presentations from the first } \\
\text { and second camp. } \\
\text { Participants learned how to create real time } \\
\text { captioning when presenting with } \\
\text { PowerPoint. }\end{array}$ \\
\hline $\begin{array}{r}\text { How multiple } \\
\text { means of } \\
\text { action \& } \\
\text { expression is } \\
\text { used and } \\
\text { taught }\end{array}$ & $\begin{array}{l}\text { Common for Camp } 1 \text { \& } 2 \\
\text { Participants could choose } \\
\text { preferred format when } \\
\text { presenting themselves } \\
\text { digitally prior to the camp. }\end{array}$ & $\begin{array}{l}\text { Common for Camp } 1 \& \mathbf{2} \\
\text { Contribution from the participants consisted } \\
\text { mostly of verbal } \\
\text { communication/dissemination. } \\
\text { Use of Menti, Padlet and Smartboard as } \\
\text { digital tools. } \\
\text { Participants could choose format and how } \\
\text { they presented their case. }\end{array}$ \\
\hline
\end{tabular}

In terms on the first principle of UDL, providing multiple means of engagement, there was much in common for the two types of camp in terms of planning and preparation. For recruitment for Camp 2, we asked two participants from Camp 1 to create short videos about their experience of the camp to give potential participants a better idea of what would be involved and the benefits of participating. But we would have done this if Camp 2 had been a face-to-face one. However, in terms of engagement during Camp 2, we needed to consider how to engage participants and keep them engaged.

The first issue is that when people travel physically to a course, they are largely away from other obligations (despite email and mobile phones). In the online camp, participants could come and go as they pleased and possibly multitask (e.g. being online and "in" the camp, but also attending to other activities), which made it flexible and easier to combine with other commitments. This was sometimes unfortunate when some participants prioritized camp activities, while others did not or could not. In retrospect, we learned that we could have been clearer about our expectations and which activities were mandatory and which were optional (if any). On the other hand, our online social events (dinner, quiz) were successful in creating a friendly environment which allowed participants and organizers to share experiences. 
Further, in terms of engagement during the camps, running the camp online, it felt easier for the organizers to ensure that everyone participated on equal terms, because most discussions happened in one online group. However, the perception of the participants may have been different, as there was a request to have discussions without the organizers. It was difficult to balance between facilitating flow in discussions and not intervening too much, taking on an expert role. This could be especially challenging when there was a gap in experience between organizers and participants in developing inclusive and accessible courses or simply when participants seemed reluctant to contribute and organizers stepped in to fill the silence.

In terms of providing multiple means of representation, again there were many similarities between the two camps, and moving the camp online provided good opportunities and some challenges. We had already given participants the opportunity to create a presentation in any format they wished, to emphasize the idea of multiple representations. For both camps not all participants prepared a presentation beforehand. In future we will make this requirement clearer. However, having all materials online created opportunities for illustrating and learning about multiple representations, discussing how to create and use such representations and learn about how students and teachers can have different preferences in using and perceiving different methods. When the camp is online, it becomes more natural that all materials are distributed and stored online and that activities are recorded for future use. This makes a number of processes easier and gives us greater flexibility.

In terms of providing multiple means of action and expression, in both camps we encouraged participants to choose their preferred method of presenting their case study and contributing to activities. We also discussed different ways for students to undertake different learning activities and the use of new technological tools such as Menti and Padlet to facilitate this.

\section{Conclusions}

Based on our experience of the TINEL camps and the feedback received, we can conclude that overall, the camps were a success. The set-up of the camps created a welcoming atmosphere and resulted in many interesting discussions about UDL and UDeL based on the participants previous experiences. The learning materials used at the camps were found useful by the participants. In particular, the experiences from students with disabilities were inspiring and highly appreciated. The participants suggested more extensive use of short videos and more examples on what works from both student and teacher perspectives as future developments.

The main purposes of the camps were to raise staff's awareness and knowledge about inclusive education and UDeL and to create a UDeL Peer Support Network. In particular, teaching about inclusive online learning in a digital format, as in now happening with the TINEL online camps, provides a huge potential for learning about inclusive online approaches, methods, and tools for both organizers and participants.

To conclude, running a second camp online was easier as we had already developed course materials and gained experiences and feedback from running a first face-to-face camp. As the structure and content of the two camps were quite similar, we could focus on incorporating specific aspects to make the online camp as inclusive and accessible as possible. Analyzing preparations and implementations of the two camps in relation to 
the UDL principles, we learned that many of the choices we made methodologically in many ways were consistent with the UDL principles.

Here are suggestions for online teaching situations in relation to the UDL principles. Engagement:

- Recruit participants who are self-motivated to participate.

- Ask participants to bring their own case study to work with and discuss.

- Clarify mandatory/voluntary activities.

- Clarify expectations and share agenda on beforehand.

- Foster collaboration and stimulate a welcoming atmosphere through interactive group work and social activities.

- Create multiple opportunities to receive and share feedback.

Representation:

- Present information in multiple formats and ensure the documents and learning material are accessible.

- Vary approaches, methods, activities and tools.

- Video tape important presentations to be viewed countless of times.

Action and expression:

- Give participants the possibility to choose preferred format when handing in assignments.

- Give participants the opportunity to choose how they communicate.

- Use technical interaction tools like Menti and Padlet to vary how participants contribute to discussions.

- $\quad$ Provide different opportunities to provide feedback during and after the online teaching activity.

\section{Acknowledgements}

We would like to thank all the UDeL camp participants for their engagement during the camps, their contributions to the learning materials and their feedback about the camps. We would like to thank the Erasmus + Programme of the European Union for co-funding the TINEL Project.

\section{References}

[1] K. Novak, and S. Bracken, Universal design for learning: a global framework for realizing inclusive practice in higher education. In S. Bracken and K. Novak (Eds.). Transforming higher education through university design for learning: An international perspective (pp. 1-8), Routledge, UK, 2019.

[2] S. Goldsmith, Designing for the disabled: a manual of technical information, Royal Institute of British Architects, UK, 1963.

[3] S. Goldsmith, Universal design, Routledge, UK, 2007.

[4] S. Goldsmith, Designing for the disabled: the new paradigm, Routledge, UK, 2012.

[5] Center for Universal Design (n.d.). About Universal Design, Available at: https://projects.ncsu.edu/ncsu/design/cud/about_ud/about_ud.htm [Accessed 22 March 2021]

[6] R.L. Mace, G.J, Hardie, J.P Place, Accessible environments: Towards Universal Design. In W.E. Preiser, J.C. Vischer, E.T. White (Eds.). Design Intervention: Toward a More Humane Architecture (pp. 155177), Van Nostrand Reinhold, USA, 1991. 
[7] E. Steinfeld, and J. Maisel, Universal design, John Wilen \& Sons Inc., Hoboken, NJ, 2012.

[8] C. Stephanidis, User interfaces for all: New perspectives into human-computer interaction. In C. Stephanidis (Ed.). User Interfaces for All: Concepts, Methods, and Tools (pp. 3-17), Lawrence Erlbaum Associates Inc., USA, 2001.

[9] J. Clarkson, R. Coleman, S. Keates, and C. Lebbon, Inclusive design: design for the whole population, Springer-Verlag, London, 2003.

[10] International Standards Organisation (ISO), ISO/IEC Guide 71:2001 - Guidelines for standards developers to address the needs of older persons and persons with disabilities, ISO, Geneva, 2001.

[11] B. Shneiderman, Universal usability, Communications of the ACM 43, 5 (2000), 85-91.

[12] H. Persson, H. Åhman, A.A. Yngling, and J. Gulliksen, Universal design, inclusive design, accessible design, design for all: different concepts - one goal? On the concept of accessibility - historical, methodological and philosophical aspects, Universal Access to the Information Society, 14, 4 (2015), 505-526.

[13] Center for Applied Special Technology (n.d.). About Universal Design for Learning, Available at: http://www.cast.org/impact/universal-design-for-learning-udl [Accessed 22 March 2021]

[14] Center for Applied Special Technology (2018). Universal Design for Learning Guidelines version 2.2., Available at: http://udlguidelines.cast.org [Accessed 22 March 2021]

[15] World Wide Web Consortium (2018). Web Content Accessibility Guidelines version 2.1 Available at: https://www.w3.org/TR/WCAG21/ [Accessed 22 March 2021]

[16] World Wide Web Consortium (2021). Web Content Accessibility Guidelines version 3.0: First public working draft Available at: https://www.w3.org/TR/wcag-3.0/ [Accessed 22 March 2021]

[17] TINEL Project website (n.d.). Available at: https://www.hamk.fi/projects/tinel/?lang=en [Accessed 22 March 2021]

[18] M. Saarela, H. Eftring, H. Petrie, A.B. Torkildsby, and T. Ladonlahti, Improving Accessibility of eLearning in Higher Education from Universal Design for Learning Perspective, HAMK Unlimited Journal (2019). Available at: https://unlimited.hamk.fi/ammatillinen-osaaminen-ja-opetus/improvingaccessibility-of-elearning/\#.YFmeWK_0nb0 [Accessed 23 March 2021]

[19] M. Romppanen (2020). "Songs of Life" - Video-documentary as a part of Bachelor's Thesis, Available at: http://urn.fi/URN:NBN:fi-fe2020042722649 [Accessed 23 March 2021]

[20] M.E. Matre, R. Andersen, M.S. Thormodsæter, and M.O. Cifuentes (2019). Digital Competence Providing Tools to Create an Inclusive eLearning Course, Available at: http://urn.fi/URN:NBN:fife2020051127189 [Accessed 23 March 2021]

[21] J. Háhn (2019). Crossing Borders Without Travel: Virtual Exchange Practices for Students, Available at: http://urn.fi/URN:NBN:fi-fe2020051127190 [Accessed 23 March 2021]

[22] M.J. Lehtonen, J.Y. Chew, K.S. Schilli, and A. Varadarajan (2019). Nordic Rebels: A Blended Approach to Fix Higher Education, Available at: http://urn.fi/URN:NBN:fi-fe2020051127192 [Accessed 23 March 2021]

[23] European Union (2016). Directive (EU) 2016/2102 of the European Parliament and of the Council of 26 October 2016 on the accessibility of the websites and mobile applications of public sector bodies. Available at: https://eur-lex.europa.eu/eli/dir/2016/2102/oj [Accessed 22 March 2021]

[24] J. Kelly, (2019). Accessibility regulations - what you need to know. Available at: https://www.jisc.ac.uk/guides/accessibility-regulations-what-you-need-to-know [Accessed 22 March 2021]

[25] C. Magnusson, A. Larsson, A. Warell, H. Eftring, and P.-O. Hedvall, Bringing the mobile context into industrial design and development, NordiCHI'12: Proceedings of the 7th Nordic Conference on HumanComputer Interaction: Making Sense Through Design. (2012), 149-152.

[26] Certec (2017). Context Cards and the Haptimap Project. Available at: https://www.certec.lth.se/ud/context-cards-and-the-haptimap-project/ [Accessed 22 March 2021]

[27] J.W. Baker, The origins of "The Classroom Flip", Proceedings of the $1^{\text {st }}$ Annual Conference on Higher Education Flipped Learning. (2016), 15-25.

[28] J. Nouri, The flipped classroom: for active, effective and increased learning - especially for low achievers, International Journal of Educational Technology in Higher Education 13, 33 (2016), 1-10.

[29] Mentimeter (n.d.). Available at: https://www.mentimeter.com/ [Accessed 22 March 2021]

[30] J. Rudolph, A brief review of Mentimeter: a student response system, Journal of Applied Learning \& Teaching 1 (2018), 35-37.

[31] Padlet (n.d.). Available at: https://padlet.com/ [Accessed 22 March 2021]

[32] Q. Zhi, and M. Su, Enhance Collaborative Learning by Visualizing Process of Knowledge Building with Padlet, Proceedings of the 2015 International Conference of Educational Innovation through Technology. (2015), 221-225.

[33] A.C.K. Gramming, E. Ejemyr, and E. Thunell, Implementing Nano-Learning in the Law Firm, Legal Information Management, 19, 4 (2019), 241-246 